\title{
An Ecofeminist Study of Saul Bellow's Herzog
}

\author{
WANG Miaomiao (Corresponding author)
}

Ph.D, Associate Professor, School of English Language and Literature

North China Electric Power University

Beinong Road 2, North China Electric Power University (NCEPU), Beijing, China

\section{CHEN Rumeng}

School of English Language and Literature, North China Electric Power University Beinong Road 2, North China Electric Power University (NCEPU), Beijing, China

Received: January 10, 2022 Accepted: January 27, 2022 Published: January 28, 2022

doi:10.5296/jsel.v10i1.19515 URL: https://doi.org/10.5296/jsel.v10i1.19515

\begin{abstract}
Saul Bellow is a famous Jewish American writer who won the Nobel Prize in Literature in 1976 for Herzog, which is about the life of an intellectual after his divorce from his second wife, and the author has created a number of distinctive female characters and ecological thinking in the book. This paper makes a close reading of Herzog from the perspective of ecofeminism, analyzing the state of urban nature and rural areas in the industrial society, as well as the situation of traditional women and modern women in the patriarchal society, and then revealing the oppression of nature and women in the context of anthropocentrism and male hegemony. This paper aims to arouse people's reflection on the situation of women and nature, so as to achieve harmony between human and nature.
\end{abstract}

Keywords: Saul Bellow; Herzog; Ecofeminism; Patriarchy 


\section{Introduction}

Saul Bellow (1915-2005), a Jewish writer in the American literary world. Since Saul Bellow published his first anti-fascist short story in 1936, he has written and published 11 novels, 3 novellas, 4 collections of short stories and one drama in his lifetime. Bellow won the National Book Award three times for his novels The Adventures of Auggie March, Mr. Symmler's Planet and Herzog. The novel Humboldt's Gift published in 1975 won the Pulitzer Prize. In 1976, he won the Nobel Prize in Literature with Herzog. The award speech pointed out: Saul Bellow "combined colorful tramp novels with subtle analysis of contemporary culture."

Herzog is the peak of Bellow's own career and the peak of American fiction in the 1950s, making it difficult for subsequent writers to match. The novel tells a typical American Jewish intellectual in the 1960s. The protagonist Herzog is a university professor. He was married twice but failed. The second wife, Madeleine, had an affair with his friend Valentine and kicked him out of the house. While wandering around, he kept writing letters to various people to express his anger towards his ex-wife and Valentine, as well as his dissatisfaction with the atmosphere of the society as a whole. Herzog returned to his childhood home and took an old gun left by his father. He wanted to kill Madeleine and Valentine in extreme anger. But when he saw Valentine patiently bathing his little daughter, he lost his determination to kill. Finally, Herzog and his lover Ramona returned to their homes in the country and finally found their home in love and nature.

This paper aims at a close reading of Herzog from the perspective of ecofeminism, analyzing the state of urban nature and rural areas in the industrial society, as well as the situation of traditional women and modern women in the patriarchal society, and then revealing the oppression of nature and women in the context of anthropocentrism and male hegemony. The purpose is to cause people to reflect on the situation of women and nature, so as to achieve harmony between human and nature.

\subsection{Literature Review}

Since its publication, Bellow's Herzog has attracted much attention from numerous scholars. Many literary critics regard Herzog as "a well-nigh faultless novel" (Kiernan 95). Up till now, studies on Herzog at home and abroad have achieved fruitful results.

\subsubsection{Research Abroad}

Before Saul Bellow was awarded the Nobel Prize in literature in 1976, he was already well known in American literary circles. Herzog, as his most outstanding work, has received extensive attention from scholars. Studies abroad can be mainly divided into four parts: the analysis of characters, the theme of Herzog, the literary genre, and the satiric style.

Firstly, with respect to the literary genre of this novel, letter-writing, Cardon Lauren in his work "Herzog as "Survival literature" describes that "Bellow establishes a parrallel between Herzog's experience of suffering and the condition of the modern world, still traumatized by the Holocaust"(85). On the theme, Chavkin argues that "Demonstrates the extent to which Bellow's Humanist roots lie in the romantic tradition, and the extent to which he fights 
Hobbesian and nihilist estimates of human existence"(48). What's more, the satiric style is also a good point to analyze the work. Robert Colbert concludes that "Bellow's vision, like that of his nineteenth-century Russian and English predecessors, is ultimately a humane and comic one; but he has frequent recourse to satiric devices"(22).

\subsubsection{Research at Home}

Scholars at home studied Herzog mainly from four perspectives: the Jewishness, the narrative skills, the feminism and existentialism.

With regard to the Jewishness, Bellow illustrates a consistently Jewish philosophical view in his works. In his master's thesis, "The Jewishness in Saul Bellow's Herzog", Yao Di discussed at length the Jewishness of his works. Zhang Yue compares the three novels (Dangling Man, The Dean's December and Herzog) and analyzes the Jewishness in his works (211). In terms of the narrative skills, some critics regard Herzog as a novel in which plural voices and conflicting truth values coexist. "On the Narrative Skills of Herzog" written by Hua Xiang starts with the analysis from the narrative level of the novel. In addition, some studies are carried out from the perspective of feminism to analyze the images of women and the problems of gender exposed in Herzog. For example, "Feminist Behavior, Feminism, and Representation -- Women in Herzog" written by Wang Yan (113) presents the view that in Herzog, the images of Madeleine and Ramona created by Bellow reflect women's awakening of themselves and their living conditions, as well as their mental outlook of ordinary professional women in the new era: self-confidence, self-esteem and self-reliance. What's more, the spiritual dilemma of intellectuals in Herzog have also attracted more attention. Fan Yue takes existential scholars Martin Heidegger and Jean-Paul Sartre's idea as the basis to analyze the different methods the character used in his pursuit of self (5).

To summarize, there are various studies on Herzog which are mainly carried out so as to investigate Jewishness, existentialism and narrative techniques reflected in the novel. However, among the previous studies, there are some papers on ecology in Herzog, but few people have analyzed the work from an ecofeminist perspective. This paper will supplement this part.

\subsection{Ecofeminism}

Francoise d'Eaubonne (1920-2005), the French feminist, who was recognized as a pioneer in the field of ecofeminist theory, proposed the term "ecofeminism" in her book Le Feminisme ou la Mort in 1974. She called for an ecological revolution among women. Women are privileged in this ecological revolution because of their natural connection to nature, which will cause us to rethink gender relations. Therefore, ecofeminism will re-emphasize the status of women and nature. Other representative figures of this school include Greta Calaire Gaard, Susan Griffin, Val Plumwood, etc.

Greta Calaire Gaard summarizes the main ideas of ecofeminism in her representative Ecofeminism Literary Criticism, and she strengthens 'Human should not attempt to 'manage' or control nonhuman species but ought to work with the land"(157). In her work Woman and Nature: The Roaring Inside Women, Susan Griffin compares women to animals, and try to 
emphasize the connection between women and nature.

Ecofeminism (ecological feminism) is the product of the combination of the women's liberation movement and the ecological movement. Ecofeminism is a political and social movement, an important genre in the third wave of feminism. It believes that there is a relationship between the oppression of women and the exploitation of nature. Ecofeminist theorists believe that sexism, control of nature, racial discrimination, speciesism, and other social inequalities are interrelated (Val Plumwood 22).

Ecofeminism opposes anthropocentrism and androcentrism, and advocates changing the idea of human beings ruling nature, and believes that this idea comes from the idea of man ruling woman. It criticizes patriarchal cultural values and praises the nature of beauty, but it is not completely essentialist. It opposes values that can lead to exploitation, domination, and offensiveness. (Val Plumwood 22). At the same time, ecofeminism starts by criticizing the hierarchical dualism and domination logic in modern Western worldviews, and points out how this "scientific" worldview of androcentric, analytic, and mechanistic has caused the West Men's oppression of nature and women (and different ethnic groups, etc.), and pointed out that these different oppressions regard women/nature as the other, so that they believe that the movement of liberating women and respecting nature must be recognized and carried out at the same time. Because this understanding binds the liberation of women to the liberation of nature, ecofeminists recognize the immanence value of nature, believing that the value of human beings, other species and the earth are equal, and constitute an indivisible organic overall. After experiencing two feminist movements, the awakening of female consciousness and the self-reflection of the patriarchal society quietly merged into subsequent literary works. Herzog published by Saul Bellow provides us with a suitable text for studying ecofeminism.

\section{Oppression of Women and Nature under Patriarchy}

Fundamentally speaking, under the influence of the patriarchal ideology in the traditional Jewish culture and the patriarchal consciousness in the American Christian culture, men are still consciously or unconsciously attempting to occupy, restrain, and discipline women. At the same time, in a technologically advanced industrial society. Under the circumstances, human beings continue to conquer, transform, and destroy nature. Neither women nor nature can escape the fate of being oppressed and exploited under the patriarchy.

\subsection{Destroyed Natural Environment}

In the 1960s, the development of science and technology in the United States created an abundance of material life and improved the living conditions of mankind. However, the spiritual world of human beings has become a "wasteland" lacking love, affection, humanitarianism, dignity and faith. The political, social, and ideological turmoil in the United States is directly reflected in literary creation, or indirectly has an impact on the author's creative thinking. Herzog is a typical work produced in this historical period. The book has detailed descriptions of the destroyed natural environments in the industrial society. 
When he first arrived in Ludeyville, in order to please his new wife Madeleine, Herzog used all the inheritance his father had left him to buy a large house in the country. When he patrolled the house, he was full of dislike for everything in this country house:

It was unpainted, gloomy, with rotting Victorian ornaments. Nothing on the ground floor but a huge hole like a shell crater. The plaster was coming down-moldy, thready, sickening stuff hung from the laths. The old fashioned knob-and-tube wiring was dangerous. Bricks were dropping from the foundations. The windows leaked(124).

When he settled in Ludeyville, he was not impressed by the natural scenery of the countryside, but devoted himself to transforming this dilapidated shelter. This is the bad part of human nature. No matter where they go, they must be selective about nature, and often transform nature according to their own preferences. In Herzog's eyes, Ludeyville was an unattractive place: Through a chink he saw the fiery morning of high summer, the wicked spiny green of vines, and the tight, shapely heads of wild roses, the huge elm in front, dying on him, the oriole's nest, gray and heart-shaped(124).

Due to the unsatisfactory life of the second marriage, Herzog has an indescribable disgust every time he thinks of Ludeyville. He subjectively vilified these supposedly beautiful rural landscapes. In the context of anthropocentrism, people destroy nature for their own benefit, so nature has to become ugly. Human beings have an aversion to the current harsh natural environment and lack of reflection, which leads to the deterioration of ecological issues.

\subsection{Female Survival Dilemma}

Due to the huge blow caused by the second marriage and the identity of the middle-class intellectual, Herzog often consciously reflects on his behavior. He actually understood that his first wife was virtuous and sensible, and knew that his fickle temperament and brutal temper "brought out the very worst in Daisy"(131) . Daisy, as a poor wife who works hard:

She took Moses' word for it that he was seriously occupied. Of course a wife's duty was to stand by this puzzling and often disagreeable Herzog. She did so with heavy neutrality, recording her objections each time-once but not more. The rest was silence(131).

Herzog was extremely satisfied with his first wife, Daisy, except that this woman had no personality. Herzog's first marriage was a marriage in a typical patriarchal society. Not only does the husband regard his wife as a servant of the family and a tool for childbirth, but the wife herself also thinks so. This is a consensual and pathological relationship between the sexual relations. Wives only need to take care of their husbands' daily life and meet their husband's physiological needs. They don't need to have their own thoughts, their own pursuits, and they only need to obey the husband's control blindly. This is the poison of androcentrism on women, not only exploiting women's physical labor, but also enslaving women's spirit.

Madeleine had an affair with Valentine, and Valentine's wife Phoebe has always known about 
it, but she never made a lot of noise. Even when Herzog asked her to cooperate in breaking up the shady couple, Phoebe still deceived herself and said, "I really don't understand what you're saying"(275). The only business of Phoebe is to please her husband and protect her child. In Phoebe's mind, as long as Valentine does not propose to divorce her, she can continue to deceive herself and defend her husband. All her fate is in the control of her husband. Once Valentine chooses to abandon his wife and children, Phoebe will be immediately homeless. Women under the long-term oppression of male hegemonism have lost themselves, facing unfair treatment, and even lacking the courage to resist, they can only put all the initiative in the hands of the cheating husband.

Sono is a Japanese woman Herzog once loved. She is obedient and kind, and only requires Herzog to be with her. But Herzog chose to abandon Sono in order to get Madeleine. He understood that "the woman was waiting for him to call", but only "when Madeleine was too busy with the Church and refused to see him", did he think of going to see Sono(107). Herzog could see her breathless every time he went to find her. "She had run to meet him and beat him home by seconds." The poor woman was worried that Herzog had been waiting for her for too long, and she was worried that she was too expectant that Herzog didn't care about him enough. But in Herzog's eyes, the preparations she made were to "show that she had an independent and active life; she did not sit waiting"(182). Sono loves Herzog and even goes against her father's wishes and does not go back to Japan. During the troublesome time when Herzog was divorced with Daisy, he often went to the Sono's house, and she helped him bathe and massage, which gave him a lot of physical and mental relaxation and joy. However, Herzog never visited her once during the month she was suffering from lung disease. She was just the woman Herzog thought of occasionally when she was tortured inwardly.

Such traditional women are usually not independent personally and spiritually. Their main focus of life is on their husbands and children. In order to preserve the integrity of the family, they sacrifice their dignity and endure all the betrayal done by their husbands. They even lied for their husbands in front of outsiders. They are completely reduced to men's accessories. In the face of the spiritual oppression from men, traditional women under patriarchy are powerless. No matter what kind of injustice they suffer, they can only choose to swallow it.

\subsection{Intimacy between Nature and Women}

There is an intimacy between women and nature under patriarchy. When women get close to nature and are cured by the beauty of nature, they often become happy and attractive. While in Ludeyville, Madeleine was wrapped by the vitality of nature, showing a state of excitement:

Under such stimulation, Mady's face did strange things. The tip of her nose moved, and her brows, which needed no help from cosmetics, rose with nervous eagerness, repeatedly, as if she were trying to clear her eyesight... The redeyed cicadas, squat forms vividly colored, were wet after molting, sopping, immobile; but drying, they crept, hopped, tumbled, flew, and in the high trees kept up a continuous chain of song, shrilling”(Bellow, 73). 
Women are often compared to animals in nature by men. For example, when Herzog persuaded Phoebe, he said, : "You've let Madeleine drive you here and there. As if you were a nanny goat... You have your own war with Madeleine, I suppose, fighting over the man. A cat fight---a female sex fight"(275). Herzog instinctively compares Phoebe to a sheep and a cat that are being slaughtered by others, which confirms the weak position of women in society, which has the same experience as the nature that is constantly being exploited by human beings. Ecofeminism pays attention to the equal oppressive position of women and nature in patriarchal society. It is because of the equal oppressive position that women have a natural sense of intimacy with nature. The oppression of women and the conquest of nature are rooted in male hegemony. In patriarchal society, men are always dominant. In this dual hierarchy, women and nature are excluded from the mainstream culture and become marginalized "others".

\section{Resistance of Women and Nature}

In order to make the harmony among all things to achieve sustainable development, we must get rid of the previous hierarchical relationship model and form a benign relationship of mutual dependence. There is no hierarchy in nature. It is human beings who imposes their own social ills on nature, regardless of the diversity of species. This violent domination of nature by human beings will inevitably lead to a challenge to patriarchy, thus leading to the revolt of nature and women.

\subsection{The Revenge of Nature to Anthropocentrism}

Under Madeleine's so-called conspiracy, the Herzog family moved to Chicago. Compared to Ludeyville, Chicago's environment disgusted him even more:

Where the thick walls and buckled slabs of pavement in the Negro slums exhaled their bad smells. Farther West, the industries; the sluggish South Branch dense with sewage and glittering with a crust of golden slime; the Stockyards, deserted; the tall red slaughterhouses in lonely decay(291).

It seems that he is born hostile to the external natural environment. In Herzog's eyes, the city was stinking everywhere. Sewage, garbage, and ruins can be seen everywhere. Human living environment is supposed to be beautiful and livable, but now it has become this awful look:

When the car left the lake front he opened his eyes on the yellow ugliness of 22nd Street. He recognized the familiar look of summer damnation. Chicago! He smelled the hot reek of chemicals and inks coming from the Donnelly plant(302).

New York also lacks any beauty in his eyes. Population growth and human blindly excessive production activities have led to ecological imbalances, and various environmental pollution phenomena have become increasingly prominent. The air that should have been fresh has been polluted by various toxic exhaust gases. In the process of blindly conquering and destroying nature, human beings also receive their own retribution: 
They were demolishing and raising buildings. The Avenue was filled with concrete-mixing trucks, smells of wet sand and powdery gray cement. Crashing, stamping pile-driving below, and, higher, structural steel, interminably and hungrily going up into the cooler, more delicate blue. Orange beams hung from the cranes like straws(33).

The human living environment, the pursuit of material, has gradually swallowed up people's living space. The continuous exploitation of nature by humans has led to the imbalance of today's natural ecosystem, which has triggered a natural ecological crisis. In fact, the crazy conquest and destruction of nature by mankind is rooted in the imbalance of mankind's own spiritual ecology. The chaotic social atmosphere, the indifferent interpersonal communication, the decay of morality, and the downfall of life make us feel confused and confused, which leads to a spiritual ecological crisis. Human society, just like nature, is an organic whole. Problems in a certain part will affect the orderly operation of the whole. People's inner world is unbalanced and angers the outer natural world. And all these are manifestations of anthropocentrism. We should respect nature, protect nature, and live in harmony with nature in order to form a virtuous circle between the internal world and the external world.

\subsection{The Rebellion of Women to Patriarchy}

Herzog's second wife, Madeleine, is the fullest and most individual modern female character in the novel. Not only is she very beautiful and charming in appearance, she has a lively, straightforward and candid personality, but she is also talented and studious. Madeleine's every move in life is full of different charms. Take cutting bangs for example: She picked up a pair of large tailor's shears and put them to her bangs. She seemed to have no need to measure; her image was fixed in her will. She cut as if discharging a gun, and Herzog felt an impulse of alarm, short-circuited(115).

Madeleine is confident and decisive in life, which is in sharp contrast with traditional Jewish women. This is very attractive in Herzog's eyes. This new female image will arouse his desire to conquer and possess. Outstanding women in a patriarchal society are more likely to be conquered in the eyes of men, but once they are conquered, they no longer put in more effort. For example, Herzog's first wife, Daisy, was also very beautiful in Herzog's eyes when she was young, but she was too conservative and could not satisfy Herzog's sense of conquest and could only be abandoned in the end.

And Madeleine was born in an artistic family and lacked father's love since she was a child. The reason why she chose to marry Herzog was because she valued his knowledge and respect for her beliefs. But the married life of the two is not satisfactory. When Herzog's friend Shapiro admired Madeleine's talents and suggested that she go to Chicago to study for graduate school, Madeleine was very happy because her husband had never valued her studies so much. Herzog "watched his wife, on whom he doted (with a troubled, angry heart, another oddity among hearts) as she revealed the wealth of her mind to Shapiro"(69). He was angry that his wife showed her talent in front of friends. In his opinion, his wife is his own accessory, and her radiance should not overshadow his husband. Especially in front of men, women should curb their talents and give up the stage to their husbands: 
Shapiro. While you and Madeleine were tossing your heads, coquetting, bragging, showing off your clean sharp teeth-the learned badinage-I was trying to take stock of my position. I understood that Madeleine's ambition was to take my place in the learned world. To overcome me. She was reaching her final elevation, as queen of the intellectuals, the castiron bluestocking. And your friend Herzog writhing under this sharp elegant heel(79).

When she saw Madeleine talking to other men, Herzog thought that his wife was just showing off with men. He regarded Madeleine's academic ambitions as an attempt to defeat him and take his place. When Madeleine was no longer under his control and restraint, he felt flustered, constantly belittling her personality and slandering her intentions to suppress her progress.

Different from traditional women, modern women have awakened their feminine consciousness. They usually have independent personalities, and they are also economically independent new women. In their lives, there are not only husbands and children, but also their own hobbies and career pursuits. But even though the consciousness of female group has made such great progress, in a deeply rooted patriarchal society, they will also be exploited and harmed by male groups.

\section{Reconstruction of Balanced World}

The exploitation of women and nature reveals the violent nature under patriarchy. Women and nature should not be considered as "others", recognizing their ontological status is the premise of rebuilding the structure of human society. Ecofeminism is not only about feminism and environmentalism, but attempts to provide a solution to environmental degradation and women's liberation. The way humans treat nature is connected with the way humans treat themselves. For the sustainable development of mankind, the diversity of species cannot be ignored. Rethinking the relationship between humans and nature, and between humans and society, is a significant task.

\subsection{Compromise between Men and Women}

Herzog returned to the country, and Ramona rushed to hear the news. The house in the country was in dilapidated condition and needed to be fired, powered on, and cleaned, but Herzog declined Ramona's help and decided to repair the house alone. He offered to invite Ramona to have dinner with him. He cleaned the room and arranged meals for Ramona's arrival. This was the beginning of his equal treatment towards women. He began to respect Ramona from the heart, "Ramona was a willing worker. According to her lights. And she loved her work."(330) He began to appreciate the characteristics of modern women in Ramona:

Ramona did look like those figures of sex and swagger. But there was something intensely touching about her, too. She struggled, she fought. She needed extraordinary courage to hold this poise. In this world, to be a woman who took 
matters into her own hands(353)!

He even picked flowers to please Ramona, hoping that he was "being thoughtful, being lovable"(357). The relationship between the hero and many female characters was dominated and dominated. Through the reconstruction of my inner world, Herzog began to understand the importance of building a relationship of mutual respect and appreciation. When the traditional structure of the relationship between men and women began to break down, men learned to reflect on themselves and gradually realized the good qualities of women as independent individuals, so as to establish a new equal relationship.

\subsection{Human's Integration with Nature}

After two failed marriages, Herzog lived on the edge of the contradiction between ideal and reality for a long time, feeling extremely painful and anxious. Fortunately, after being cured by his family, friends and lovers, he gradually recovered his spiritual balance. At this time he seems to be reborn: How marvelously beautiful it is today. He stopped in the overgrown yard, shut his eyes in the sun, against flashes of crimson, and drew in the odors of catalpa-bells, soil, honeysuckle, wild onions, and herbs(325).

This land is far from the hustle and bustle, and the scenery is quiet and beautiful. Herzog finally learned to enjoy the beauty of nature. He used to think animals were disgusting and annoying, but now they look so lively and cute. When he was making a fire, he deliberately only lit a small pile of fire and added a little dry wood to try his best to give the insects a chance to escape. Everything in the world becomes equal in his eyes. He will feel uneasy and painful because of the death of some birds:

A strange odor in the toilet bowl attracted his notice next, and raising the wooden lid he found the small beaked skulls and other remains of birds who had nested there after the water was drained, and then had been entombed by the falling lid. He looked grimly in, his heart aching somewhat at this accident(328).

He found that the bird died unexpectedly because of the existence of human residence, and he felt very guilty. In order to prevent more animals from dying because of him, he carefully checked each room to see if there were other animals nesting here:

Indeed, he found owls in his bedroom, perched on the red valances, which they had streaked with droppings. He gave them every opportunity to escape, and, when they were gone, looked for a nest. He found the young owls in the large light fixture over the bed. He didn't want to drive the owls out of the house and leave a brood to die in the old fixture with the triple brass chain(336).

At this time, he was full of awe and attachment to nature. He put aside the ambition of mankind to conquer nature and treat all things in nature as equals. He wandered around this small country courtyard, feeling sad that he had missed so many opportunities for appreciation before. He noticed that his mental and physical condition was better than ever. In the purification of nature, he is full of confidence and hope for the future. Berkshire is like a paradise, giving Herzog energy and inspiration to prepare for a new life. 


\section{Conclusion}

Bellow successfully portrayed a number of female images in Herzog. But it is undeniable that these female characters reflect Bellow's "angel" or "siren" view of women. He does not hesitate to praise traditional Jewish women, and at the same time, he unilaterally degrades and ridicules modern new women. Analyzing this work from the perspective of ecofeminism, it is not difficult to see that patriarchal consciousness are the main sources of misogyny. Herzog, the protagonist in the work, was even more representative of anthropocentrism in the early stage, and relied on subjective desires to transform and vilify nature. Later, as the protagonist's mental shock gradually subsided and his heart became calm, Herzog truly understood how to live in harmony with nature, and at the same time he understood that he respected and cared for women, and finally reaped a harmonious and happy life. Only by observing gender equality and respecting nature can human civilization develop harmoniously and sustainably.

\section{Acknowledgements}

Research for the above paper has been supported by Project of Humanities and Social Sciences, Ministry of Education of the People's Republic of China: "A Study of Chinese Culture and its Images in US-American Newspapers in the New Media Era" (Project No. 19YJCZH162), University-Industry Collaborative Education Program, Ministry of Education of the People's Republic of China (Project No. 20190215002), and Fundamental Research Funds for the Central Universities (Project No. 2020MS056).

\section{References}

Bellow, Saul. (2001). Herzog. Penguin Modern Classics.

Cardon, Lauren. (2004). “Herzog as 'Survival Literature”. Saul Bellow Journal 20. 2: 85-108. Chavkin, Allan. (1979). Bellow's Alternative to the Wasteland: Romantic Theme and Form Herzog. Studies in the Novel.

Gaard, Greta. (1993). Ecofeminism: Women, Animals, Nature.

Gaard, Greta. (1998). Ecofeminist Literary Criticism: Theory, Interpretation, Pedagogy.

Gaard, Greta. (2001). Ecofeminism on the wing: perspectives on human-animal relations. Women and Environments International Magazine.

Kiernan, Robert F. (1989). Saul Bellow. The Continuum Publishing Company.

Plumwood, Valerie. (1993). Feminism and the Mastery of Nature. London: Routledge.

Wilson, J. (1990). Herzog: The Limits of Ideas.

程锡麟.(2012). 书信、记忆、与空间一重读《赫索格》. 外国文学, 2012(5):45-52. 


\section{IIMacrothink}

訤悦. (2015). 索尔. 贝娄小说主人公精神解放和存在意义的追寻一一试从存在主义角度 解读《雨王汉德森》、《赫索格》、《拉维尔斯坦》, (Doctoral dissertation, 上海外国语 大学).

华翔. (2009). 论《赫索格》的叙事技巧. (Doctoral dissertation, 山东大学).

李袁菲, 刘玲玉, 贾维灿, 等. (2021). 生态女性主义视角下的《简・爱》。青年文学 家,2021(3):119-120.

林阳扬. (2014). 女性及她们生活的环境-从生态女性主义试析《赫索格》[J]. 英语广场(下 旬刊）,2014(6):40-41. DOI:10.3969/j.issn.1009-6167(x).2014.06.019.

普鲁姆德, 薇尔. (2007). 女性主义与对自然的主宰[M].马天杰、李丽丽, 译. 重庆: 重庆 出版社.

王嫣. (2007). 女性行为、女性主义和再现一《赫索格》中的女性. 广西民族大学学报: 哲学社会科学版, 29(B12), 3.

姚迪. (2017). 论索尔·贝娄《赫索格》的犹太性, (Doctoral dissertation, 安徽大学).

\section{Copyright Disclaimer}

Copyright for this article is retained by the author(s), with first publication rights granted to the journal.

This is an open-access article distributed under the terms and conditions of the Creative Commons Attribution license (http://creativecommons.org/licenses/by/4.0/). 